\title{
POSTGLACIAL ISOSTATIC MOVEMENT IN NORTHEASTERN DEVON ISLAND, CANADIAN ARCTIC ARCHIPELAGO
}

\author{
F. Müller* and W. Barr*
}

\begin{abstract}
Raised marine features of the lowlands in the vicinity of Cape Sparbo were investigated. The carbon ${ }^{14}$ dates of marine shells indicate that the area was clear of ice as early as 15,500 before present and that the most rapid isostatic uplift (approx. $6.5 \mathrm{~m}$. per century) took place between 9,000 and 8,000 years ago; the total isostatic rebound having been about $110 \mathrm{~m}$. The two oldest dates $(15,000$ and 13,000 B.P.), if correct, give a rare indication of the slow onset of the isostatic uplift.
\end{abstract}

RESUMÉ. Isostasie postglaciaire dans le nord-est de l'ille Devon, Archipel Arctique canadien. Les auteurs ont étudié la morphologie isostatique des basses terres au voisinage du cap Sparbo. Les datations par le carbone ${ }^{14}$ de coquillages marins indiquent que la région était libre de glace dès 15,500 av. p. et que le relèvement le plus rapide (approx. $6.5 \mathrm{~m}$. par siècle) s'est produit entre le neuvième et le huitième millénaire av. $\mathrm{p}$. Le rebondissement isostatique total a été d'environ $110 \mathrm{~m}$. Les deux datations les plus anciennes $(15,000$ et 13,000 av. p.), si elles sont justes, sont une rare preuve de la lenteur du relèvement à son début.

АБСТРАКТ. ПОСЛЕЛЕДНИКОВОЕ ИЗОСТАТИЧЕСКОЕ ДВИЖЕНИЕ В СЕВЕРО ВоСТОЧНОЙ ЧАСТИ ОСТРОВА ДЕВОН, Канадские Арктические острова. Исследуются морские черты характера низменности, поднявшейся из моря в районе мыса Спарбо. Определение возраста ракушек углеродным (14) методом указывает, что рай0н этот был свободен ото льда уже 15000 лет тому назад, и что напболее быстрое изостатическое поднятие (приблизительно 6,5 метров в столетие) имело место между 9000 и 8000 лет тому назад. Полная изостатическая компенсация достигала высоты около 110 метров. Если самый ранний возраст в 15000 и 13000 лет до напего времени определен правильно, то он указывает на редкий случай медленного начального пропесса изостатического поднятия.

* Университет Макгила, Географический факультет.

7 The Base Camp of the Devon Island Expedition, 1961-63, of the Arctic Institute of North America, is situated on a lowland about $25 \mathrm{~km}$. SW. of Cape Sparbo on the north shore of Devon Island, $75^{\circ} 41^{\prime} \mathrm{N}$. and $84^{\circ} 33^{\prime} \mathrm{W}$. (Fig. 1). Marine shells collected by Müller in 1962 on the numerous raised beaches and beach ridges in the Base Camp area were dated by the radiocarbon method (M. Stuiver, Yale Radiocarbon Laboratory). In the summer of 1965, Barr continued this investigation and extended it to the Sparbo-Hardy lowland. Some preliminary results are presented here.

The raised beaches on the northern shore of Devon Island have been discussed by various people (Cook 1911; Wordie 1938; Roots 1963), with speculation on the movement of the land relative to sea level but with no attempt at absolute dating. Quantitative information on the marine limit and on isostatic movements in the eastern part of the Canadian Arctic Archipelago would contribute to the knowledge of the extent of the last glaciation of the islands, the thickness of the ice cover and the mode and timing of deglaciation.

Physiographically the area contains two main elements: the interior plateau

* Department of Geography, McGill University. 


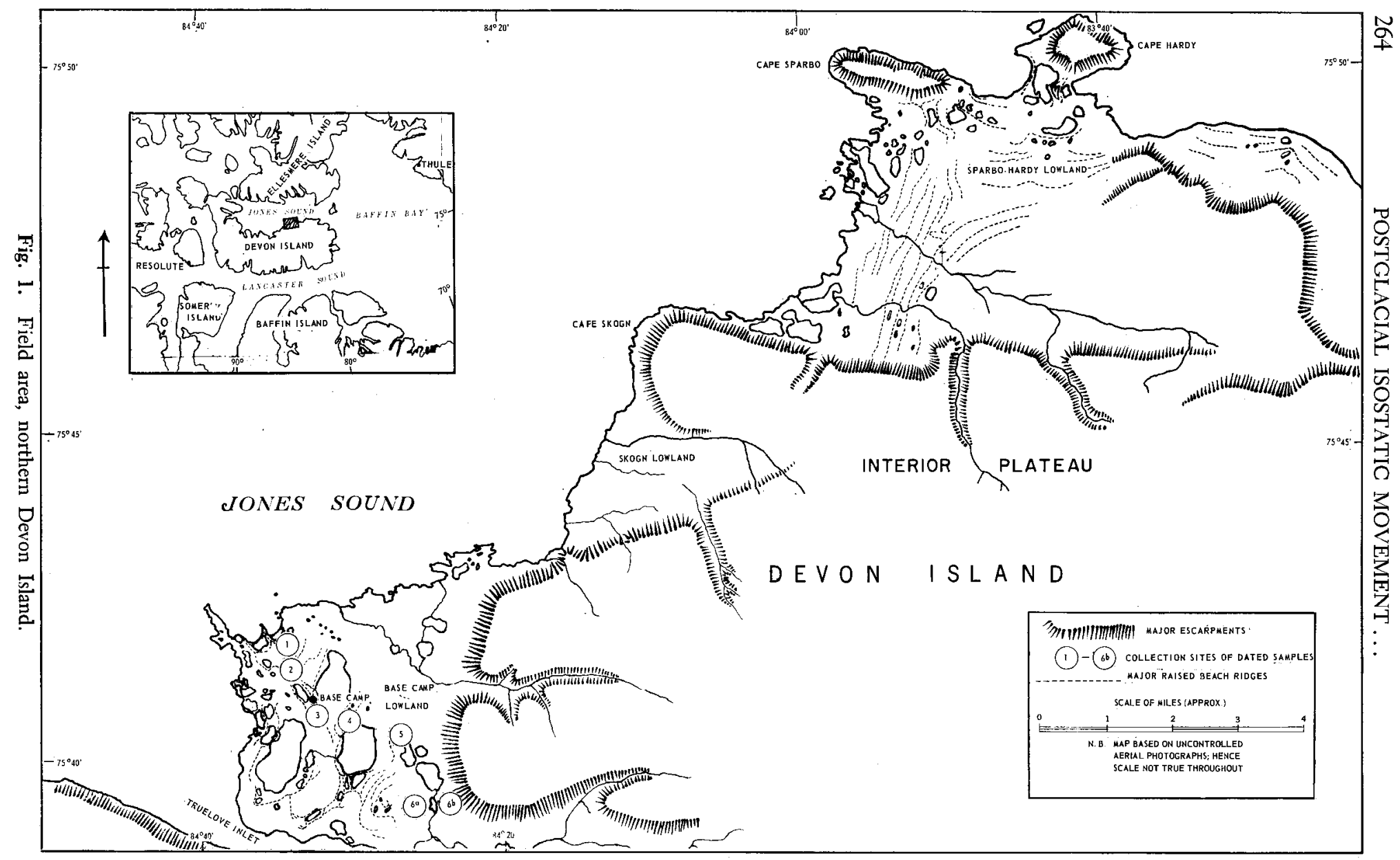


with a surface elevation of about $300 \mathrm{~m}$. a.s.l., and the coastal lowlands. The two are clearly separated by a series of bold escarpments. The geology of the area is described by Glenister (1963) and Roots (1963).

The limit of marine submergence of the last glaciation varied considerably in altitude over the $30 \mathrm{~km}$. of coast investigated. It was found at an elevation of approximately $65 \mathrm{~m}$. in the Base Camp lowland, $82 \mathrm{~m}$. in the Skogn area and $73 \mathrm{~m}$. in the Sparbo-Hardy lowland. Such variations can be explained in part by differences in the time of deglaciation.

The pronounced raised beach ridges, in both the Base Camp and SparboHardy lowlands, frequently separate either lakes or marshy flats floored with a very viscous yellow silt. These ridges appear to result from the action of a falling sea level on a very gradual slope. As can be seen clearly in both areas at the present time, this produces a spit-and-lagoon type of coast. In many cases the spits start as offshore break-point bars between two headlands. Their emergence above the surface is aided by the ploughing-up and deposition of material by pressure ice and by icebergs and floes, some of which become stranded on these bars after break-up. In several places, as between Cape Sparbo and Cape Hardy, a line of breakers and a line of stranded ice floes after break-up indicated where the next beach ridge could be expected to emerge. Once the bar has emerged above the surface, it usually encloses a tidal lagoon, drained by one or more gaps between recurved spits. With further uplift, the bar becomes a raised beach ridge, broken at fairly regular intervals by dry gaps, which were once the tidal entrances to the lagoons. The lagoons themselves are transformed into fresh-water lakes or low-lying marshes. Most of the raised beach ridges contain abundant shells of marine molluses; the locations of the major ridges, including those from which shell samples were collected, are shown in Fig. 1.

The sample localities, their elevation above present sea level and the elevation after a correction has been applied for eustatic rise of sea level, together with the ages of the dated samples, are given in Table 1.

There was some difficulty in establishing accurate elevations for the locations where specimens were collected due to the lack of a reliable datum level. The short open water season (less than two months) and a tidal range of 2-3 m. made it impossible, as yet, to establish the mean sea level; the mean sea ice surface and the high-water mark were used as the reference level. The accuracy of the elevation values in Table 1 is given in relation to this ill-defined level.

A correction of $0.9 \mathrm{~m}$. per century for the period 16,000 to 6,000 years B.P. was added to the measured altitude to allow for the mean eustatic rise of sea level as established by Godwin et al. (1958, p. 1518), Fairbridge (1961, p. 156, Fig. 14), Shepard $(1961$, p. $31 ; 1963$, p. 2) and as applied by Washburn and Stuiver (1962, p. 66, Figs. 3 and 4). Corrections based on Graul (1960, Abb. 2 and 3) would generally be similar, although somewhat smaller during the period 9,000 to 6,000 B.P. No adjustment is made for eustatic rise of sea level during the last 6,000 years as mean sea-level fluctuations remained relatively small during this period.

The dates obtained for the samples, after correction for isotopic fractionation, have been reduced by an amount of 500 years, an adjustment necessary to compensate for the average $\mathrm{C}^{14}$ deficiency of Arctic shells (Stuiver, personal communication). 
Table 1. Radiocarbon dates of marine shells from the Base Camp lowland, Devon Island

\begin{tabular}{|c|c|c|c|c|c|}
\hline $\begin{array}{l}\text { SAMPLE } \\
\text { NO. }\end{array}$ & $\begin{array}{l}\text { LABORATORY } \\
\text { NO. }\end{array}$ & $\begin{array}{c}\text { LOCALITY } \\
\text { AND TYPE OF SAMPLE }\end{array}$ & $\begin{array}{c}\text { FIELD } \\
\text { ELEVATION } \\
\text { (m. above } \\
\text { datum) }\end{array}$ & $\begin{array}{l}C^{14} \text { AGE } \\
\text { (years } \\
\text { before } \\
1950 \text { ) }\end{array}$ & $\begin{array}{l}\text { ELEVATION (m) } \\
\text { corrected for } \\
\text { eustatic rise } \\
\text { of sea level }\end{array}$ \\
\hline 1 & $\mathrm{Y}-1294$ & $\begin{array}{l}\text { 'Meat Cache'; beach } \\
\text { ridge about } 30 \mathrm{~m} \text {. E. of a } \\
\text { small limestone outcrop; } \\
\text { abundant well-preserved } \\
\text { Hiatella arctica in fine- } \\
\text { grained centres of pat- } \\
\text { terned ground. }\end{array}$ & $3.4 \pm 0.5$ & $6980 \pm 120$ & $12.2 \pm$ \\
\hline 2 & $Y-1295$ & $\begin{array}{l}\text { 'Whale Bone'; field of } \\
\text { patterned ground sloping } \\
\text { slightly seaward between } \\
\text { two irregular beach ridges } \\
\text { (whale skeleton embed- } \\
\text { ded): well-preserved } \\
\text { Hiatella arctica and Mya } \\
\text { truncata. }\end{array}$ & $7.7 \pm 0.5$ & $7750 \pm 160$ & $23.5 \pm$ \\
\hline 3 & $\mathrm{X}-1296$ & $\begin{array}{l}\text { 'Air Strip': broad beach } \\
\text { ridge S. of Base Camp, } \\
1-2 \mathrm{~m} \text {. higher than sur- } \\
\text { rounding; marine shells } \\
\text { (mainly Hiatella arctica). }\end{array}$ & $15.5 \pm 1.0$ & $8240 \pm 120$ & $35.7 \pm$ \\
\hline 4 & Y-1297 & $\begin{array}{l}\text { 'Fish Lake'; broad irregu- } \\
\text { larly shaped ridge, about } \\
1 \mathrm{~m} \text {. lower than a similar } \\
\text { parallel one some } 60 \mathrm{~m} \text {. } \\
\text { seawards: marine shells. }\end{array}$ & $23 \pm 1.5$ & $15500 \pm 240$ & $108.5 \pm$ \\
\hline 5 & Y-1298 & $\begin{array}{l}\text { 'First Muskox Lake'; } \\
\text { large irregular ridge, in } \\
\text { part like terrace rem- } \\
\text { nants; marine shells at } \\
\text { edges and in some active } \\
\text { frost boils. }\end{array}$ & $38 \pm 2$ & $13120 \pm 200$ & $102.5 \pm$ \\
\hline 6 & $\mathrm{Y}-1279$ & $\begin{array}{l}\text { Main portion of marine } \\
\text { shell sample collected at } \\
\text { or near edge of a large } \\
\text { terrace on } \mathrm{SE} \text {. side of the } \\
\text { highest hill between Base } \\
\text { Camp lowland and True- } \\
\text { love Valley and the rest } \\
\text { is shell fragments found } \\
\text { at same elevation in the } \\
\text { well-developed beach ter- } \\
\text { races at foot of escarp- } \\
\text { ment to E. }\end{array}$ & $60 \pm 4$ & $8860 \pm 160$ & $85.5 \pm$ \\
\hline
\end{tabular}

One of the most serious difficulties encountered when applying a date from mollusc shells arises from the fact that they can live and their primary deposition can take place many metres below sea level. The four species most commonly found in the Devon Island Base Camp area are, in order of frequency: Hiatella arctica (Linné), Mya truncata Linné, Astarte borealis (Schumacher) and Macoma calcarea (Gmelin). Off Point Barrow (Alaska), they have been observed to reach their present optimal ecological condition at depths of $20 \mathrm{~m}$. and more (MacGinitie, 1955, pp. 173-74).

In Fig. 2 the radiocarbon ages of the shells are plotted in relation to elevation, and curves from other investigators (Olsson and Blake 1961, Fig. 9; Washburn and Stuiver 1962, Fig. 2; Ives 1964, Fig. 3; Henoch 1964, Fig. 6; Løken 1965, Fig. 7) are given for comparison. Samples 4 and 5 are not included in this graph as they are clearly out of sequence and indicate an anomaly for which only a tentative explanation can be offered. Their great ages could be due to an error - in the laboratory testing, in the numbering of the samples, or arising 
Fig, 2. Postglacial emergence of northern Devon Island compared with other High Arctic areas.

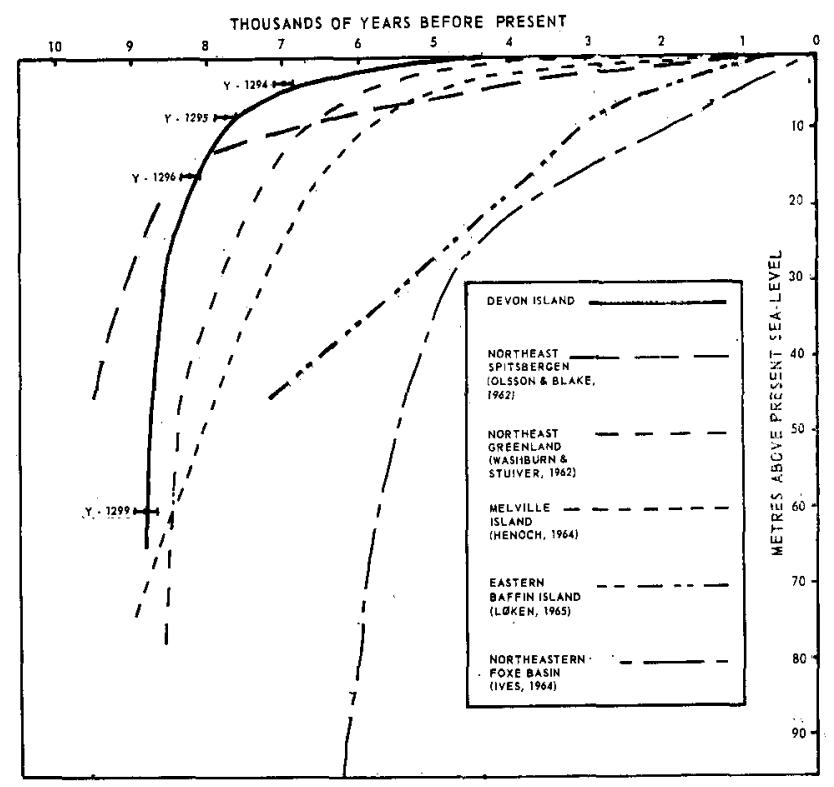

from the inclusion of 'old', i.e. interstadial or interglacial, shells. Assuming that no such errors have been introduced the following hypothesis is put forward.

The samples 4 and 5 were deposited during the early stages of the isostatic recovery, and at that time the rate of eustatic rise of sea level was greater than that of the actual uplift of the land. Sample 4 -the oldest, with an age of 15,500 years - and sample 5, 13,000 years old, were collected at some $37 \mathrm{~m}$. and $22 \mathrm{~m}$. respectively, below the highest level bearing marine shells. Assuming that the beaches are of the same age as the shells, they would subsequently have been submerged by the rapid eustatic rise in sea level between 16,000 and 6,000 years B.P. These two beach ridges, and perhaps others in the area - survived this submergence. On the seaward side, each of them is paralleled by another similar, but younger, ridge of equal or slightly greater height, which may have protected the older beach from destruction by wave action and sea-ice pressure.

In Fig. 3 the dated samples are plotted against the elevations that have been corrected for the eustatic rise of sea level, and samples 4 and 5 are included. The curve is, as in Fig. 2, drawn slightly above the sample point to make a symbolic allowance for the fact that these molluscs live and can be deposited at various depths below sea level. It is clear that 6 samples do not provide sufficient points to determine a final isostatic uplift curve, but as this curve, if correct, gives a rare indication of the onset of the postglacial isostatic uplift, it is presented here in the hope that it will encourage the collection of further data.

Certain tentative conclusions are drawn from the present material:

1. The Devon Island Base Camp lowland may have been free of ice as early as 15,500 years B.P. Fyles (1963, pp. 35-36) and Fyles and Blake (1965) state that the classical Wisconsin ice margin must have withdrawn from the southern shore of Viscount Melville Sound more than 12,400 years ago, and Blake (1964, p. 4) shows that much of Bathurst Island was ice-free by 9,000 years ago. 


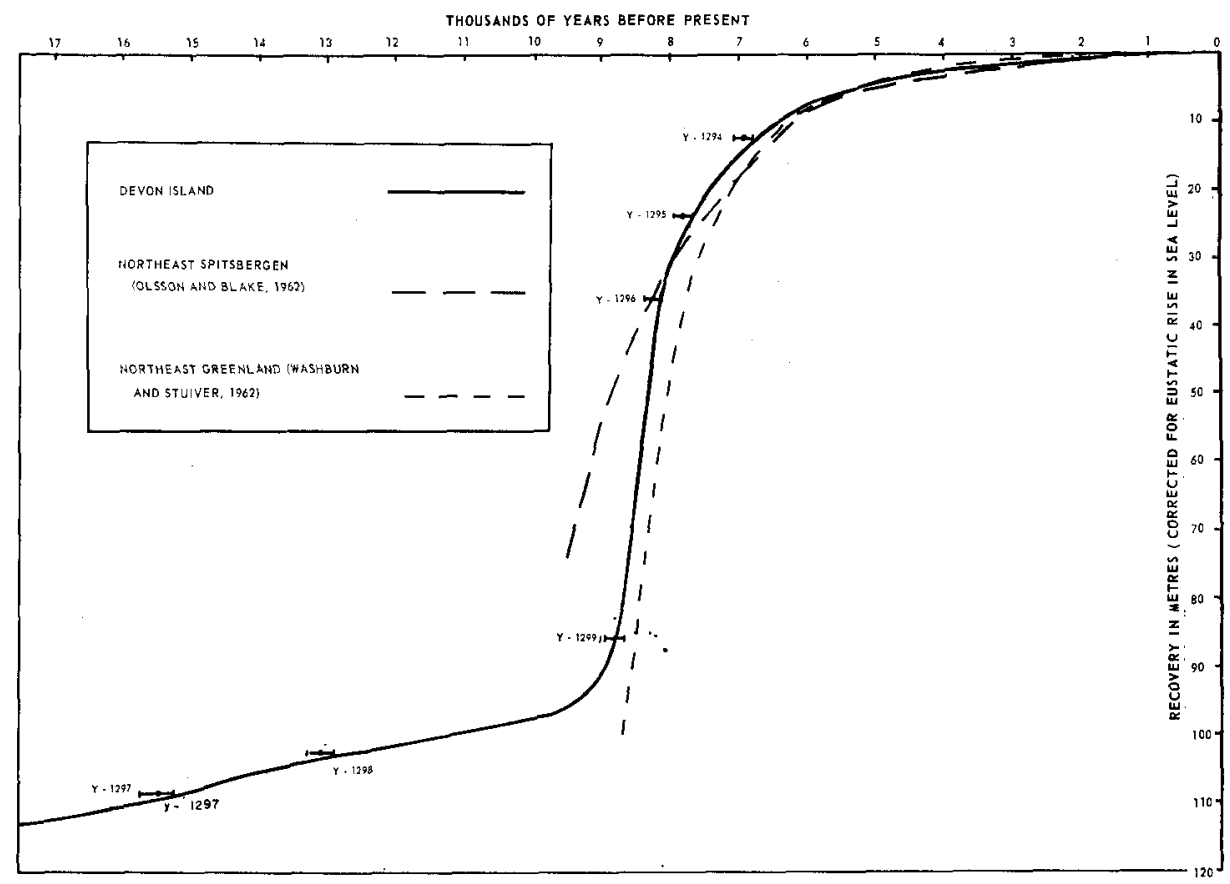

Fig. 3. Preliminary curve of isostatic uplift, Base Camp lowland, Devon Island, Canadian Arctic Archipelago, compared with other High Arctic areas.

2. During the early phase of the isostatic uplift, 15,500 years until about 9,500 years B.P., the eustatic rise of sea level of some $50 \mathrm{~m}$. exceeded by approximately $30 \mathrm{~m}$. the amount of isostatic movement.

3. The total isostatic uplift for northeastern Devon Island must have been approximately $110 \mathrm{~m}$. or somewhat more.

4. The rate of isostatic uplift during the most rapid phase, i.e. about 9,000 years to 8,000 years B.P., would have amounted to as much as $6.5 \mathrm{~m}$. per century. This value is somewhat smaller than that found by Washburn and Stuiver (1962, p. 71) for Northeast Greenland ( $9 \mathrm{~m}$. per century) and that calculated from the data published by Lee (1960 and 1962, p. 242) for the Hudson Bay area $(7.5 \mathrm{~m}$. per century). The rapid uplift in the latter area seems to have taken place somewhat later than on Devon Island; the uplift in eastern Baffin Island appears to have occurred even later and to have been less rapid and more prolonged (Løken 1965).

5. Since about 6,000 years B.P., the rate of uplift on northeastern Devon Island has greatly decreased.

6. The similarity in character of the Devon Island curve and those of some other places in northern Canada, Northeast Greenland, and Spitsbergen (Figs. 2 and 3) testifies to the glacial isostatic, rather than tectonic, origin of the movement. 


\section{Acknowledgements}

The fieldwork for this study was supported by the Arctic Institute of North America. Dr. M. Stuiver of the Yale Radiocarbon Laboratory very kindly carried out the $\mathrm{C}^{14}$ analysis. The authors are also indebted to Drs. J. G. Fyles and Weston Blake of the Geological Survey of Canada, for most helpful discussions and to the latter for his valuable comments on the manuscript.

\section{References}

Blake, W., Jr. 1964. Preliminary account of the glacial history of Bathurst Island, Arctic Archipelago. Geol. Surv. of Can. Pap. 64-30, 8 pp.

Cook, F. A. 1911. My attainment of the pole. New York and London: Mitchell Kennerly, $604 \mathrm{pp}$.

Fa rbridge, R. W. 1961. Eustatic changes in sea level. In: Physics and Chemistry of the Earth, Vol. 4. New York: Pergamon Press, pp. 99-181.

Fyles, J. G. 1963. Surficial geology of Victoria and Stefansson Islands, District of Franklin. Geol. Surv. of Can. Bull. 101, 38 pp.

Fyles, J. G. and W. Blake. 1965. Glaciation of the northwestern Canadian Arctic Islands. In: Abstracts, International Association for Quaternary Research, VII International Congress, Boulder and Denver, Colorado, U.S.A., p. 156.

Glenister, B. F. 1963. Sverdrup Inlet to Cape Sparbo (Regional Geology). Geol. Surv. of Can., Memoir 320 (Geology of the north-central part of the Arctic Archipelago Northwest Territories (Operation Franklin)), pp. 184-88.

Godwin, H., R. P. Suggate and E. H. Willis. 1958. Radiocarbon dating of the eustatic rise in ocean level. Nature, 181: 1518-19.

Graul, H. 1960. Der Verlauf des glazialeustatischen Meeresspiegel-anstieges berechnet an Hand von C-14 Datierungen. Deutscher Geographentag Berlin. Tagungsbericht und wissenschaftliche Abhandlungen. Franz Steiner Verlag, Wiesbaden, pp. 232-42.

Henoch, D. E. S. 1964. Postglacial marine submergence and emergence of Melville Island, N.W.T. Geog. Bull. No. 22, pp. 105-26.

Ives, J. D. 1964. Deglaciation and land emergence in northeastern Foxe Basin. Geog. Bull. No. 21, pp. 54-65.

Lee, H. A. 1960. Sakami Lake. Map 52-1959 with marginal notes. Geol. Surv. of Can.

1962. Method of deglaciation, age of submergence, and rate of uplift west and east of Hudson Bay, Canada. Biuletyn Peryglacjalny, 11: 239-45.

Løken, O. H. 1965. Postglacial emergence at the south end of Inugsuin. Fiord, Baffin Island, N.W.T. Geog. Bull. 7:243-58.

MacGinitie, G. E. 1955. Distribution and ecology of the marine invertebrates of Point Barrow, Alaska. Smithsonian Misc. Coll., Vol. 128, No. 9, 201 pp.

Olsson, I. and W. Blake. 1962. Problems of radiocarbon dating of raised beaches, based on experience in Spitsbergen. Norsk Geografisk Tidsskrift, Bd. 18, pp. 47-64.

Roots, E. J. 1963. Physiography (Devon Islands): also Cape Sparbo area (Regional Geology). Geol. Surv. of Can., Memoir 320 (Geology of the north-central part of the Arctic Archipelago, Northwest Territories (Operation Franklin)), pp. 164-79, 189-94.

Shepard, F. P. 1961. Sea level rise during the past 20,000 years. Zeitschrift für Geomorphologie, Supplement 3, pp. 30-35.

1963. Thirty-five thousand years of sea level. Essays in Marine Geology in Honor of K. O. Emery, Los Angeles: University of Southern California Press, pp. 1-10.

Washburn, A. L. and M. Stuiver. 1962. Radiocarbon-dated postglacial delevelling in Northeast Greenland and its implications. Arctic, 15, 66.73.

Wordie, J. M. 1938. An expedition to North West Greenland and the Canadian Arctic in 1937. Geog. J., 92:385-421. 